\title{
Changes in the renin angiotensin system during the development of colorectal cancer liver metastases
}

\author{
Jaclyn H Neo*1, Eleanor I Ager ${ }^{1}$, Peter W Angus², Jin Zhu' ${ }^{1}$, Chandana B Herath² and Christopher Christophi
}

\begin{abstract}
Background: Blockade of the renin angiotensin system (RAS) via angiotensin I converting enzyme (ACE) inhibition reduces growth of colorectal cancer (CRC) liver metastases in a mouse model. In this work we defined the expression of the various components of the RAS in both tumor and liver during the progression of this disease.

Methods: Immunohistochemistry and quantitative RT-PCR was used to examine RAS expression in a mouse CRC liver metastases model. CRC metastases and liver tissue was assessed separately at key stages of CRC liver metastases development in untreated (control) mice and in mice treated with the ACE inhibitor captopril $(750 \mathrm{mg} / \mathrm{kg} /$ day). Nontumor induced (sham) mice indicated the effect of tumors on normal liver RAS. The statistical significance of multiple comparisons was determined using one-way analysis of variance followed by Bonferroni adjustment with SAS/STAT software.

Results: Reduced volume of CRC liver metastases with captopril treatment was evident. Local RAS of CRC metastases differed from the surrounding liver, with lower angiotensin II type 1 receptor (AT1R) expression but increased ANG-(1-7) receptor (MasR) compared to the liver. The AT1R localised to cancer and stromal infiltrating cells, while other RAS receptors were detected in cancer cells only. Tumor induction led to an initial increase in AT1R and ACE expression while captopril treatment significantly increased ACE expression in the final stages of tumor growth. Conversely, captopril treatment decreased expression of AT1R and angiotensinogen.

Conclusions: These results demonstrate significant changes in RAS expression in the tumor-bearing captopril treated liver and in CRC metastases. The data suggests the existence of a tumor-specific RAS that can be independently targeted by RAS blockade.
\end{abstract}

\section{Background}

Colorectal cancer (CRC) is a leading cause of cancer death worldwide, with approximately 940000 new cases and 500000 deaths reported annually [1]. Mortality from $\mathrm{CRC}$ is primarily due to metastasis to the liver, accounting for over $70 \%$ of deaths [2]. Surgical resection provides the best chance of cure. However, only $20 \%$ to $25 \%$ of patients are eligible for surgery, with recurrence rates approaching $40 \%$ to $70 \%$ [3,4]. Palliative systemic chemotherapy is the preferred option for the majority of these patients.

\footnotetext{
* Correspondence: j.neo@pgrad.unimelb.edu.au

1 Department of Surgery, The University of Melbourne, Austin Health, Heidelberg, Victoria, Australia

Full list of author information is available at the end of the article
}

Recent studies suggest that therapies targeting paracrine hormone systems that promote tumor development may provide an alternative or additional treatment strategy in these patients. There is strong evidence that long term blockade of the renin angiotensin system (RAS) in hypertensive patients is associated with a decreased incidence of several human cancers [5]. Evidence also suggests that blockade of the RAS in experimental animal models of CRC liver metastases is associated with tumor growth inhibition [6-9]. The angiotensin I converting enzyme (ACE) is a key enzyme in the RAS, cleaving the biologically inactive angiotensin (ANG) I precursor to ANG II, the key effector peptide of the RAS. ACE inhibition is associated with a reduction in tumor growth for

(c) 2010 Neo et al; licensee BioMed Central Ltd. This is an Open Access article distributed under the terms of the Creative Commons AtB.W 1 ed Central tribution License (http://creativecommons.org/licenses/by/2.0), which permits unrestricted use, distribution, and reproduction in any medium, provided the original work is properly cited. 
several malignancies including breast, prostate, lung, and colon cancer [5,10-12].

In the liver, the local RAS is up-regulated in response to tissue injury and hypoxia $[13,14]$. However, its expression during the development of CRC liver metastases has not been examined. ANG II stimulates the expression of several growth and pro-angiogenic factors including vascular endothelial growth factor (VEGF) $[15,16]$. The proangiogenic effects of ANG II are mediated by the ANG II type 1 receptor (AT1R), which is overexpressed in several human cancers [7-19].

Recent studies demonstrate that while ANG II/AT1R signalling has proliferative and angiogenic effects, counter-regulatory effects are mediated by other RAS components. For example, activation of the AT2R, which is expressed in preference to AT1R in primary CRC, inhibits angiogenesis and cellular proliferation [20,21]. In addition, a homologue of ACE, ACE2, was recently described and its expression is up-regulated in liver injury [13,2224]. This enzyme generates the peptide ANG-(1-7) directly from ANG II and indirectly from ANG I [23]. ANG-(1-7) acts through the MasR (mitochondrial assembly receptor) and appears to antagonize some ANG II-induced effects, including angiogenesis and cellular proliferation [25-27]. Although ANG-(1-7) decreases proliferation of several cell types, including human lung cancer cells in vitro [28], it has also been associated with increased cellular proliferation $[29,30]$.

Several components of the RAS are expressed in primary CRC and we have shown previously that blockade of the RAS decreased tumor growth in a mouse model of CRC liver metastases $[8,19]$. However, the ontogeny of RAS expression during CRC liver metastases progression has not been described, nor have the effects of captopril treatment on RAS expression in tumors been documented. This study aimed to establish an expression profile of the RAS in both captopril treated and untreated early, mid, and late stages of CRC liver metastases.

\section{Methods}

\section{Animals}

Male inbred 6-8 week old CBA mice were obtained from Adelaide University Animal Facility, Australia. Experiments were performed according to the Austin Health Animal Ethics Committee guidelines.

\section{Mouse model of colorectal liver metastases}

A mouse model of CRC liver metastases was used as described previously [31]. A dimethyl-hydrazine-induced primary colon carcinoma was maintained by in vivo serial passage in the flanks of male CBA mice. Tumors were removed from passage mice and used to make a tumor cell suspension $\left(1 \times 10^{6}\right.$ cells $/ \mathrm{ml}$ in Ringers solution/0.1\% glucose). For tumor-induction, mice were anaesthetized with an intraperitoneal injection $(0.1 \mathrm{ml} / 10 \mathrm{mg}$ body weight) of ketamine/xylazine. The spleen was exteriorized through a subcostal incision. Tumor cell suspension $(0.05 \mathrm{ml})$ was slowly injected into the spleen using a $25-$ gauge needle over a period of 1 minute. The needle was retracted and even pressure was applied to the spleen for 2 minutes. A haemostatic clip sealed the splenic vessels and a splenectomy was performed. The skin was sutured and the mouse recovered on a heated pad. Sham mice had a $0.05 \mathrm{ml}$ injection of Ringers $/ 0.1 \%$ glucose solution and a splenectomy.

This model has been characterized previously and results in metastases exclusively confined to the liver [31]. Angiogenesis is established by day 10, followed by exponential growth of tumors between days 10-16, and a plateau phase from day 19-22.

\section{Sample collection}

Liver samples from 3-5 animals per time point and treatment were collected at 5, 10,16 and 21 days after CRC liver metastases induction. However, because of the small size of tumors in the early stages (days 5 and 10), analysis of CRC metastases was restricted to days 16 and 21. All effort was made to completely separate tumor from adjacent liver; however, contamination from micro metastases cannot be excluded from samples of the tumorbearing liver.

\section{Captopril treatment}

Captopril (D-3-mercapto-2-methylpropanoyl-L-proline, Sigma-Aldrich, Sydney, NSW, Australia) was made fresh in PBS. The dosing regime was as described previously [8]. Briefly, captopril was administered daily to mice via intraperitoneal injection $(750 \mathrm{mg} / \mathrm{kg}$; at a volume of 0.3 $\mathrm{ml})$. Dosing began on the day of CRC liver metastases induction and continued daily until the experimental endpoint. Control mice received an equivalent volume of PBS.

\section{RNA extraction and CDNA synthesis}

Liver and CRC metastases tissues were homogenized in 1 $\mathrm{ml}$ of Trizol (Invitrogen) to obtain total RNA. RNA was DNase treated (Ambion, DNA-free ${ }^{\mathrm{tw}}$ ) to remove contaminating genomic DNA. RNA concentration and purity were determined using a spectrophotometer. Approximately $1 \mu \mathrm{g}$ of total RNA, $100 \mathrm{ng}$ of random hexamers (Invitrogen), $2 \mu \mathrm{l}$ deoxyribonucleotide triphosphate (10 $\mathrm{mM}$ dNTP), and $2000 \mathrm{U}$ of reverse transcriptase were used in a cDNA synthesis reaction.

\section{Quantitative RT-PCR (qRT-PCR) analysis}

An aliquot of cDNA (between 5 and 100 ng of cDNA according to primer efficiency and the anticipated level of expression for each gene) was used in a qRT-PCR (ABI Prism 7700 Sequence Detector). To confirm the absence 
of contaminating genomic DNA, RT-minus and no template controls were performed. Probes and primers for mouse tissue were designed using Primer Express, Ver 1.0 (PE Applied Biosystems, Foster City, CA) and ordered from Geneworks (Table 1). Each cDNA sample was analyzed in duplicate and assessed using the comparative $C_{T}$ method. The qRT-PCR protocol began with a $50^{\circ} \mathrm{C}$ incubation for 2 minutes, followed by $95^{\circ} \mathrm{C}$ for 10 minutes, and 45 cycles at $95^{\circ} \mathrm{C}$ for 15 seconds and $60^{\circ} \mathrm{C}$ for $1 \mathrm{~min}$ ute. $18 \mathrm{~S}$ ribosomal RNA served as the internal control. Values from non-treated and treated liver and liver metastases were normalized against sham livers, which were given a value of 1 .

\section{Immunohistochemistry}

To measure RAS proteins, samples were collected in $4 \%$ paraformaldehyde and fixed for 48 hours before embedding in paraffin. Sections were cut at $4 \mu \mathrm{m}$ and mounted on SuperFrost Plus slides (Menzel-Glaser). Sections were dewaxed in two 10 minutes histolene solvent baths and rehydrated by serial progression through three 100\% EtOH baths. Endogenous peroxidase activity was blocked with $3 \%$ hydrogen peroxide in TBST for 5 minutes. For the ACE H-170 antibody (rabbit polyclonal, Santa Cruz, cat\# sc-20791) and the AT2R antibody (rabbit polyclonal, Santa Cruz, cat\# sc-9040), an antigen retrieval step in citrate buffer $(10 \mathrm{mM}, \mathrm{pH}$ 6) for 15 and 10 minutes, respectively, at low microwave power was required. AT1R and MasR immunostaining did not require antigen retrieval. The ACE H-170 antibody was applied at $0.001 \mathrm{~g} / \mathrm{L}$, the
AT1R antibody (rabbit polyclonal, Santa Cruz, cat\# sc$1173)$ at $1 \mu \mathrm{g} / \mathrm{mL}$, the AT2R antibody at $2.5 \mu \mathrm{g} \cdot \mathrm{mL}$, and the MasR antibody (rabbit polyconal, Lifespan Biosciences, cat\# LS-A1528) at $10 \mu \mathrm{g} / \mathrm{mL}$. Control sections were incubated in diluent or appropriate IgG negative control. Slides were incubated at $37^{\circ} \mathrm{C}$ for 2 hours (ACE, AT1R and the MasR antibody) or for an hour (AT2R antibody) followed by an overnight $4^{\circ} \mathrm{C}$ incubation. Slides were then incubated for 1 hour at $37^{\circ} \mathrm{C}$ with an anti-rabbit horseradish peroxidase secondary antibody (Dako, cat\# 4011). The final detection step was carried out using 3,3'-diaminobenzidine (DAB, Dako, cat\# 4011) as the chromogen. Sections were counterstained with Mayer's hematoxylin for 3 minutes and cover slipped.

\section{ACE positive cell counts}

The Nikon Coolscope digital microscope and Image Pro Plus image analysis system were used to quantify the number of cells in the tumor stroma and used each nucleus that was associated with surrounding ACE positive staining to distinguish individual cells in treated and un-treated tumors. Positively staining cells were counted per high-powered field $(20 \times$ magnification $)$ and measured relative to tumor area. For each section, between 7 and 40 images were captured (depending on the number/ size of tumors). Cell counts were averaged to give a single value for each section/individual. Between 4 and 6 individuals were assessed at each stage. Cell counts were performed on day 16 and 21 tumors, but not in the adjacent liver as ACE positive staining localized to non-sinusoidal

Table 1: Primer and probe sequences for qRT-PCR listed from the 5' to 3 ' direction.

\begin{tabular}{|c|c|c|c|c|}
\hline Gene & Primer & Size (bp) & Probe & $\begin{array}{l}\text { Size } \\
\text { (bp) }\end{array}$ \\
\hline Mas R & $\begin{array}{l}\text { Forward TGTGGGCACTITCGTGCTT } \\
\text { Reverse } \\
\text { AАTGACTCTCTTCTCCGCTGTCA }\end{array}$ & $\begin{array}{l}19 \\
23\end{array}$ & $\begin{array}{l}\text { CACCATGGAGTATGTC } \\
\text { ATGT }\end{array}$ & 20 \\
\hline ACE & $\begin{array}{l}\text { Forward } \\
\text { CAGAATCTACTCCACTGGCAAGGT } \\
\text { Reverse } \\
\text { TCGTGAGGAAGCCAGGATGT }\end{array}$ & $\begin{array}{l}24 \\
20\end{array}$ & $\begin{array}{l}\text { CAACAAGACTGCCACC } \\
\text { TGCTGGTCC }\end{array}$ & 25 \\
\hline ACE2 & $\begin{array}{l}\text { Forward TGCCCATTTGCTTGGTGAT } \\
\text { Reverse } \\
\text { AAAGGGAACAGTCAAAGGGTACAG }\end{array}$ & $\begin{array}{l}19 \\
24\end{array}$ & $\begin{array}{l}\text { ПTGTCCAAAATCTAC } \\
\text { CCСACA }\end{array}$ & 22 \\
\hline AT1R & $\begin{array}{l}\text { Forward } \\
\text { GGGCAGTITATACCGCTATGGA } \\
\text { Reverse TGGCCGAAGCGATCTTACAT }\end{array}$ & $\begin{array}{l}22 \\
20\end{array}$ & $\begin{array}{l}\text { TACCAGTGGCCCTTCG } \\
\text { GCAATCA }\end{array}$ & 23 \\
\hline AT2R & $\begin{array}{l}\text { Forward } \\
\text { ATTACCTGCATGAGTGTCGATAGG } \\
\text { Reverse AGATGCTTGCCAGGGATTCC }\end{array}$ & $\begin{array}{l}24 \\
20\end{array}$ & $\begin{array}{l}\text { ACCAATCGGTCATCTA } \\
\text { СССTITCTGTCTC }\end{array}$ & 30 \\
\hline Angioten-siongen & $\begin{array}{l}\text { Forward } \\
\text { CTGCTCCAGGCTITCGTCTAA } \\
\text { Reverse } \\
\text { AGAACTGGGTCAGTGGATAAATCC }\end{array}$ & $\begin{array}{l}21 \\
24\end{array}$ & $\begin{array}{l}\text { СССТGCССТСТTCССА } \\
\text { CGСТCTC }\end{array}$ & 23 \\
\hline
\end{tabular}


endothelial cells in all treatments and conditions and differences in staining intensity could not be assessed with the antibody used.

\section{Statistical analyses}

The statistical significance of multiple comparisons was determined using one-way analysis of variance followed by Bonferroni adjustment with SAS/STAT software. Quantitative data are presented as means \pm s.e.m.. A Pvalue less than 0.05 was defined as significant.

\section{Results}

\section{Captopril inhibits CRC liver metastases}

We previously described in detail the inhibitory effect of pharmacological blockade of the RAS on CRC liver metastases. We found that captopril administered daily at a dose of $750 \mathrm{mg} / \mathrm{kg}$ dramatically decreased the number and volume of tumors in a mouse model of CRC liver metastases [8]. In the present study, we again administered captopril using the same dosing regimen and animal model. Our present results confirm the previously documented inhibitory effect of captopril on CRC liver metastases (an example from day 21 is shown; Figure 1).

\section{RAS expression in the liver and colorectal metastases}

While the liver adjacent to CRC metastases was assessed at days $5,10,16$ and 21 by qRT-PCR, due to the small tumor size at days 5 and 10, CRC metastases samples were assessed only at days 16 and 21 . Both CRC metastases and liver samples have been normalized against the

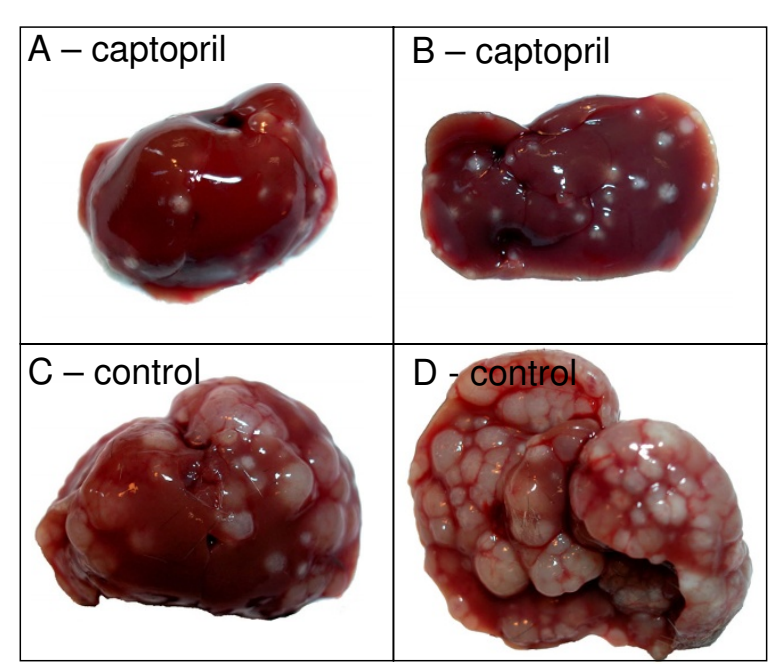

Figure 1 An example of CRC liver metastases inhibition by captopril treatment. Captopril treated livers (e.g. A, dorsal; B, ventral) had noticeably fewer metastases than the corresponding tumor-bearing controls (e.g. C, dorsal; D, ventral). Control and captopril images are to the same scale. These results confirm our previous study which described in detail the inhibitory effects of captopril on CRC liver metastases [8]. same sham livers at each time point. Statistical significance for all comparisons is presented in Table 2, while Figure 2 indicates significant differences between control and treatment groups only.

Key components of the RAS, namely angiotensinogen, ACE, ACE2, AT1R, AT2R, and the MasR were expressed in the sham liver, tumor-induced liver, and in CRC liver metastases (tumors) at all stages examined. Standard deviations between replicate samples of the same cDNA were less than 1 cycle, demonstrating the accuracy of the qRT-PCR analyses performed. Variation between liver samples between individuals may reflect contamination from micrometastses or standard biological variation, while deviations in CRC metastases samples likely reflect the heterogeneous nature of these tumors.

\section{Angiotensinogen expression is lower in CRC liver metastases and is reduced in the liver surrounding tumors following captopril treatment}

Angiotensinogen mRNA expression in the liver surrounding CRC metastases was not significantly different from sham, indicating no effect of tumor-induction on the expression of this gene. Angiotensinogen expression in CRC metastases was unchanged by captopril treatment, with no significant difference between control and captopril treated CRC metastases at either day 16 or day 21. However, in the liver surrounding CRC metastases treatment with captopril resulted in significantly lower angiotensinogen mRNA expression at almost all time points compared to both the sham and control tumorinduced liver $(P \leq 0.0160)$ (Figure 2 and Table 2$)$.

\section{$A C E$ and $A C E 2$ expression in CRC liver metastases}

A significant increase in ACE mRNA expression was observed at day 5 in the tumor-bearing liver compared to sham livers $(P=0.0412)$, indicating an effect of tumor induction. However, the highest ACE expression levels were observed in CRC metastases. ACE mRNA expression was higher in CRC metastases compared to the surrounding liver at day $16(P=0.0007)$ and was increased markedly at day 21 by captopril treatment; captopril treated CRC metastases had significantly higher ACE expression compared control CRC metastases $(P=$ $0.0001)$ (Figure 2$)$ as well as to the surrounding liver $(P=$ $0.0001)$.

Immunohistochemical staining for ACE localized this protein to the stromal desmoplasia surrounding angiogenic vessels in CRC metastases (Figure 3). In the normal liver adjacent to $\mathrm{CRC}$ metastases, $\mathrm{ACE}$ localized to the hepatic endothelial cells of liver veins and some sinusoidal endothelial cells in both sham operated animals and in tumor-bearing control and captopril treated animals. Because no obvious difference in the number of ACEpositive cells or in the localization of positively-stained 


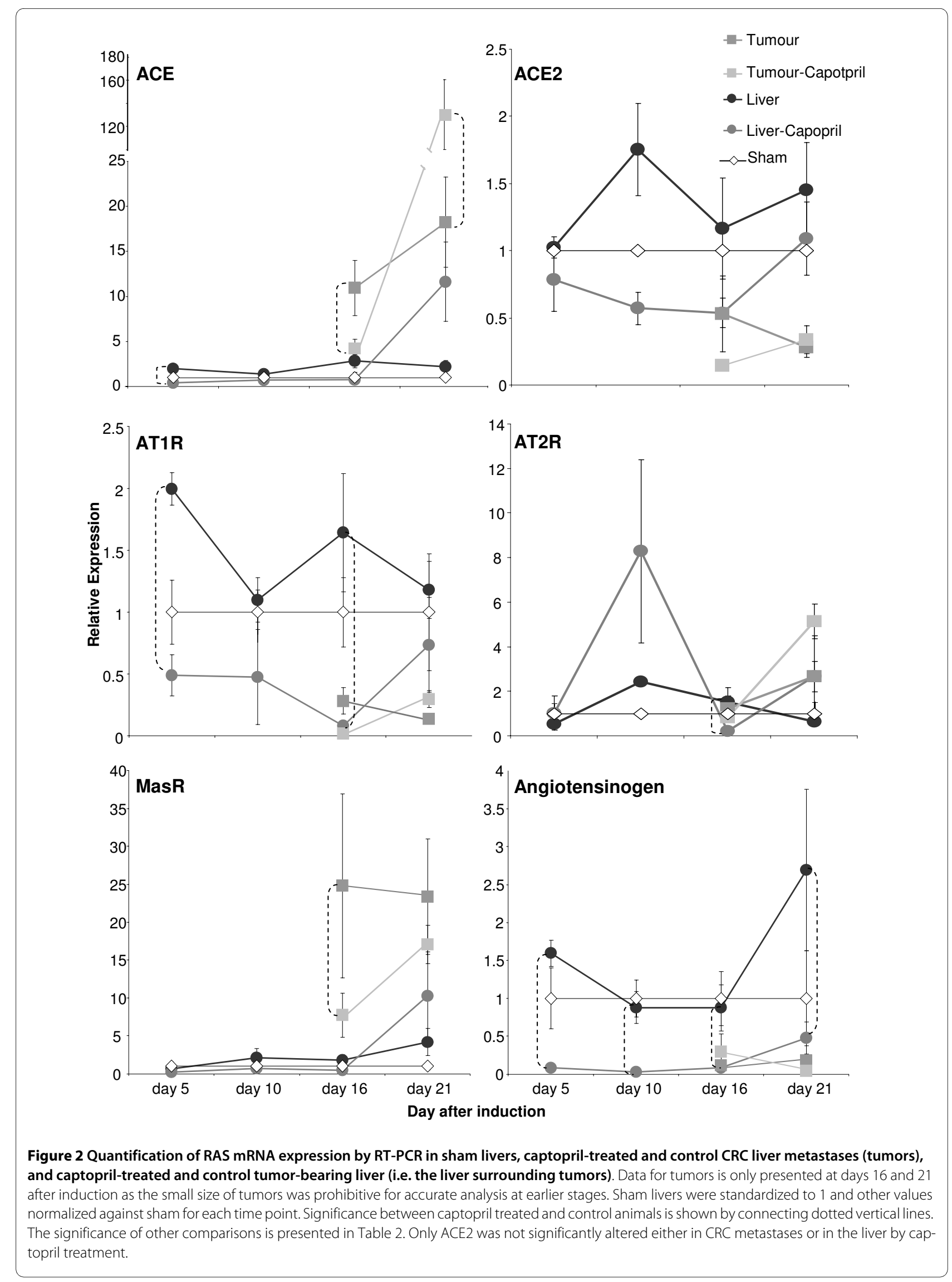


Table 2: Bonferroni adjusted t-tests for comparisons between RAS gene expression in tumors, tumor-induced liver, and sham livers either with or without captopril treatment.

\begin{tabular}{|c|c|c|c|c|c|}
\hline Gene & Comparison & Day 5 & Day 10 & Day 16 & Day 21 \\
\hline \multirow[t]{8}{*}{ ACE } & $\begin{array}{l}\text { Tumor control cf. } \\
\text { sham }\end{array}$ & & & 0.0003 & 0.3693 \\
\hline & $\begin{array}{l}\text { Tumor control cf. } \\
\text { tumor captopril }\end{array}$ & & & 0.0033 & 0.0001 \\
\hline & $\begin{array}{l}\text { Tumor control cf. } \\
\text { liver control }\end{array}$ & & & 0.0007 & 0.3508 \\
\hline & $\begin{array}{l}\text { Liver control cf. } \\
\text { sham }\end{array}$ & 0.0412 & 0.5001 & 0.4026 & 0.9496 \\
\hline & $\begin{array}{l}\text { Liver control cf. } \\
\text { liver captopril }\end{array}$ & 0.0005 & 0.2495 & 0.2839 & 0.6212 \\
\hline & $\begin{array}{l}\text { Liver captopril cf. } \\
\text { sham }\end{array}$ & 0.1202 & 0.5906 & 0.9216 & 0.6110 \\
\hline & $\begin{array}{l}\text { Tumor captopril } \\
\text { cf. sham }\end{array}$ & & & 0.1482 & 0.0001 \\
\hline & $\begin{array}{l}\text { Tumor captopril } \\
\text { cf liver captopril }\end{array}$ & & & 0.0796 & 0.0001 \\
\hline \multirow[t]{8}{*}{ ACE2 } & $\begin{array}{l}\text { Tumor control cf. } \\
\text { sham }\end{array}$ & & & 0.2276 & 0.0531 \\
\hline & $\begin{array}{l}\text { Tumor control cf. } \\
\text { tumor captopril }\end{array}$ & & & 0.2609 & 0.8660 \\
\hline & $\begin{array}{l}\text { Tumor control cf. } \\
\text { liver control }\end{array}$ & & & 0.9828 & 0.0011 \\
\hline & $\begin{array}{l}\text { Liver control cf. } \\
\text { sham }\end{array}$ & 0.9305 & 0.4077 & 0.6531 & 0.2105 \\
\hline & $\begin{array}{l}\text { Liver control cf. } \\
\text { liver captopril }\end{array}$ & 0.3797 & 0.2270 & 0.0598 & 0.3130 \\
\hline & $\begin{array}{l}\text { Liver captopril cf. } \\
\text { sham }\end{array}$ & 0.4554 & 0.6545 & 0.2146 & 0.8171 \\
\hline & $\begin{array}{l}\text { Tumor captopril } \\
\text { cf. sham }\end{array}$ & & & 0.0294 & 0.0838 \\
\hline & $\begin{array}{l}\text { Tumor captopril } \\
\text { cf liver captopril }\end{array}$ & & & 0.2259 & 0.0514 \\
\hline \multirow[t]{8}{*}{ Ang } & $\begin{array}{l}\text { Tumor control cf. } \\
\text { sham }\end{array}$ & & & 0.0119 & 0.3345 \\
\hline & $\begin{array}{l}\text { Tumor control cf. } \\
\text { tumor captopril }\end{array}$ & & & 0.7069 & 0.8632 \\
\hline & $\begin{array}{l}\text { Tumor control cf. } \\
\text { liver control }\end{array}$ & & & 0.0134 & 0.0024 \\
\hline & $\begin{array}{l}\text { Liver control cf. } \\
\text { sham }\end{array}$ & 0.0923 & 0.6725 & 0.6830 & 0.0530 \\
\hline & $\begin{array}{l}\text { Liver control cf. } \\
\text { liver captopril }\end{array}$ & 0.0004 & 0.0120 & 0.0108 & 0.0090 \\
\hline & $\begin{array}{l}\text { Liver captopril cf. } \\
\text { sham }\end{array}$ & 0.0160 & 0.0052 & 0.0098 & 0.5520 \\
\hline & $\begin{array}{l}\text { Tumor captopril } \\
\text { cf. sham }\end{array}$ & & & 0.0043 & 0.2801 \\
\hline & $\begin{array}{l}\text { Tumor captopril } \\
\text { cf liver captopril }\end{array}$ & & & 0.7858 & 0.5997 \\
\hline
\end{tabular}


Table 2: Bonferroni adjusted t-tests for comparisons between RAS gene expression in tumors, tumor-induced liver, and sham livers either with or without captopril treatment. (Continued)

\begin{tabular}{|c|c|c|c|c|c|}
\hline \multirow[t]{8}{*}{ AT1R } & \multicolumn{3}{|l|}{$\begin{array}{l}\text { Tumor control cf. } \\
\text { sham }\end{array}$} & 0.1071 & 0.0223 \\
\hline & \multicolumn{3}{|l|}{$\begin{array}{l}\text { Tumor control cf. } \\
\text { tumor captopril }\end{array}$} & 0.4844 & 0.6327 \\
\hline & \multicolumn{3}{|l|}{$\begin{array}{l}\text { Tumor control cf. } \\
\text { liver control }\end{array}$} & 0.0019 & 0.0003 \\
\hline & $\begin{array}{l}\text { Liver control cf. } \\
\text { sham }\end{array}$ & 0.0030 & 0.8065 & 0.1292 & 0.6180 \\
\hline & $\begin{array}{l}\text { Liver control cf. } \\
\text { liver captopril }\end{array}$ & 0.0001 & 0.1617 & 0.0003 & 0.2222 \\
\hline & $\begin{array}{l}\text { Liver captopril cf. } \\
\text { sham }\end{array}$ & 0.0787 & 0.2352 & 0.0360 & 0.5013 \\
\hline & $\begin{array}{l}\text { Tumor captopril } \\
\text { cf. sham }\end{array}$ & & & 0.0261 & 0.0677 \\
\hline & $\begin{array}{l}\text { Tumor captopril } \\
\text { cf liver captopril }\end{array}$ & & & 0.8570 & 0.2443 \\
\hline \multirow[t]{8}{*}{ AT2R } & \multicolumn{3}{|l|}{$\begin{array}{l}\text { Tumor control cf. } \\
\text { sham }\end{array}$} & 0.7637 & 0.2765 \\
\hline & \multicolumn{3}{|l|}{$\begin{array}{l}\text { Tumor control cf. } \\
\text { tumor captopril }\end{array}$} & 0.4973 & 0.9972 \\
\hline & \multicolumn{3}{|l|}{$\begin{array}{l}\text { Tumor control cf. } \\
\text { liver control }\end{array}$} & 0.6145 & 0.0870 \\
\hline & $\begin{array}{l}\text { Liver control cf. } \\
\text { sham }\end{array}$ & 0.4505 & 0.2186 & 0.4791 & 0.8018 \\
\hline & $\begin{array}{l}\text { Liver control cf. } \\
\text { liver captopril }\end{array}$ & 0.4651 & 0.6104 & 0.0434 & 0.1241 \\
\hline & $\begin{array}{l}\text { Liver captopril cf. } \\
\text { sham }\end{array}$ & 0.9716 & 0.4497 & 0.2960 & 0.2765 \\
\hline & $\begin{array}{l}\text { Tumor captopril } \\
\text { cf. sham }\end{array}$ & & & 0.8127 & 0.0086 \\
\hline & $\begin{array}{l}\text { Tumor captopril } \\
\text { cf liver captopril }\end{array}$ & & & 0.2897 & 0.0749 \\
\hline \multirow[t]{8}{*}{ MasR } & \multicolumn{3}{|l|}{$\begin{array}{l}\text { Tumor control cf. } \\
\text { sham }\end{array}$} & 0.0090 & 0.0033 \\
\hline & \multicolumn{3}{|l|}{$\begin{array}{l}\text { Tumor control cf. } \\
\text { tumor captopril }\end{array}$} & 0.0299 & 0.3405 \\
\hline & \multicolumn{3}{|l|}{$\begin{array}{l}\text { Tumor control cf. } \\
\text { liver control }\end{array}$} & 0.0036 & 0.0046 \\
\hline & $\begin{array}{l}\text { Liver control cf. } \\
\text { sham }\end{array}$ & 0.4294 & 0.2097 & 0.9185 & 0.6467 \\
\hline & $\begin{array}{l}\text { Liver control cf. } \\
\text { liver captopril }\end{array}$ & 0.2900 & 0.1486 & 0.8491 & 0.3546 \\
\hline & $\begin{array}{l}\text { Liver captopril cf. } \\
\text { sham }\end{array}$ & 0.0902 & 0.7769 & 0.9501 & 0.2062 \\
\hline & $\begin{array}{l}\text { Tumor captopril } \\
\text { cf. sham }\end{array}$ & & & 0.3995 & 0.0339 \\
\hline & $\begin{array}{l}\text { Tumor captopril } \\
\text { cf liver captopril }\end{array}$ & & & 0.2990 & 0.3248 \\
\hline
\end{tabular}

Tumor comparisons have only been made for days 16 and 21 due to the difficult in obtaining sufficient samples at earlier stages (days 5 and 10). Comparisons between liver tissues, however, have been made at all stages (Days 5, 10, 16 and 21 post-tumor induction). Values were considered significant for $\mathrm{P}<0.05$ (highlighted in bold). 


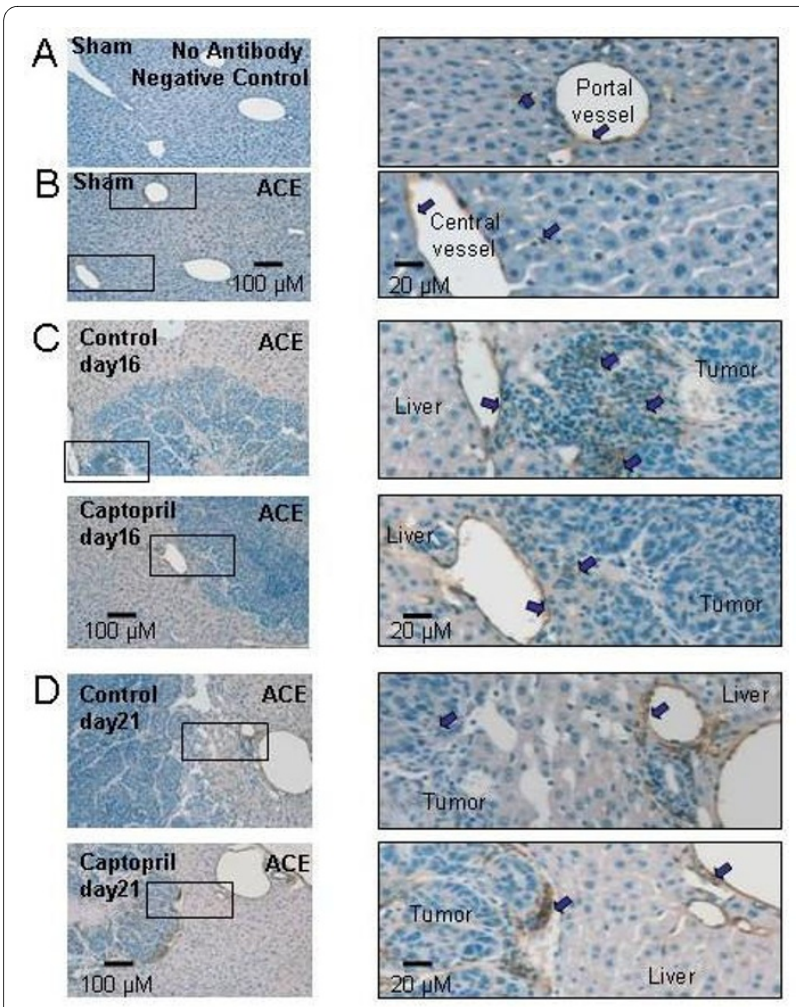

Figure 3 Immunohistochemical staining against ACE in the sham (B), control and captopril-treated animals at day 16 (C) and 21 (D). No staining was evident in the negative control (A). The sinusoidal, portal vein, and central vein endothelium stained positively for ACE in the sham liver (B), and two images at higher magnification on the right). At day 16 , there appeared to be more positive staining in control tumors compared to treated tumors (C). In contrast, at day 21 more cells stained positively for ACE when treated with captopril than when untreated (D)

cells were observed in the liver tissue, cell counts were not performed on the liver adjacent to CRC metastases. However, marked differences in the number of positively stained cells were observed in the stromal infiltrations within CRC metastases. At day 16 control tumors had significantly more ACE-positive cells compared to captopril treated CRC metastases, but ACE expression reverts back to the level seen in untreated tumors at day 21 (Figure 4). Thus, the ACE-positive cell counts reflected mRNA ACE expression in CRC metastases (Figure 2 and 4).

In contrast to ACE, ACE2 mRNA expression was lower in tumors compared to the surrounding liver at day 21 in control animals $(P=0.0011)$ (Table 2$)$.

\section{Classical and alternative RAS receptors are differentially expressed in CRC liver metastases}

AT1R expression was elevated by tumor induction at day $5(P=0.0030)$ (Table 2). AT1R expression in the liver was reduced by captopril treatment at days $5(P=0.0001)$ and $16(P=0.0003)$ (Figure 2$)$. While in control animals CRC

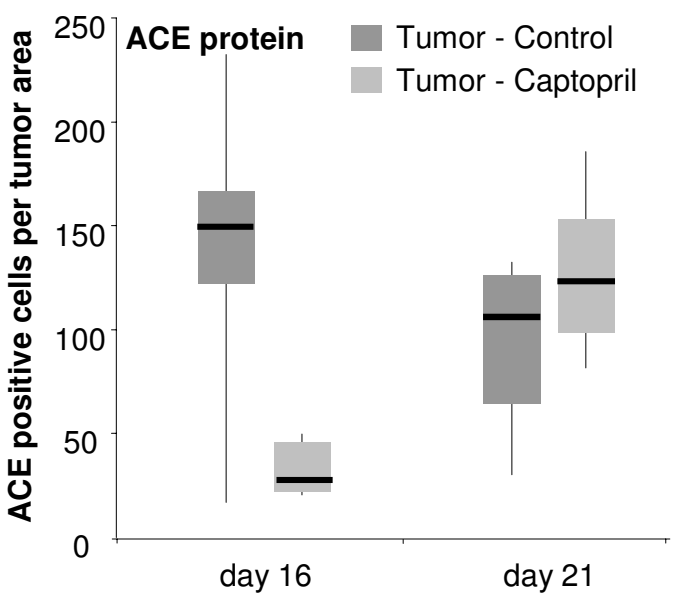

Figure 4 ACE-positive cell counts in captopril treated and untreated tumors at days $\mathbf{1 6}$ and $\mathbf{2 1}$ after tumor-induction. Because all vascular endothelial cells stained in the liver regardless of treatment with captopril, cell counts for the corresponding normal liver were not performed. Changes in the number of ACE positive cells in response to captopril treatment was similar to ACE mRNA (see Figure 2), with greater numbers and mRNA expression in untreated CRC metastases at day 16, but an increase in mRNA expression and number of ACE-positive cells by day 21 in treated CRC metastases.

metastases had significantly lower expression than the surrounding liver $(P=0.019$ day 16 and $P=0.0003$ day $21)$, there was no difference between AT1R expression in CRC metastases and liver of captopril treated animals. Indeed, AT1R expression in the liver of captopril treated animals was significantly less than the expression detected in the livers of control animals (Table 2). In contrast to the AT1R, AT2R and MasR expression was higher in CRC metastases compared to the surrounding liver, reaching significance for the MasR $(P \leq 0.0046)$ (Table 2$)$. At day 16 MasR mRNA expression also increased in tumors with captopril treatment $(P=0.0299)$ compared to control CRC metastases (Figure 2).

Immunohistochemistry for the AT1R showed localization to the stromal intrusions of CRC metastases in addition to cells lining the liver sinusoids (Figure 5). Staining on tumors cells was observed only at the periphery and was notably less intense than staining of the infiltrating stromal cells. Given their location surrounding CRC metastases and in the liver sinusoids it is likely that at least some of these AT1R-positive cells are tumor-associated macrophages (liver Kupffer cells). Consistent with our findings of AT1R mRNA expression, the number of these AT1R-positive cells appeared lower in captopril treated animals (see representative immunohistochemical images). While the AT1R localized to cells within the surrounding liver, with comparatively light staining on CRC metastases cells, only CRC metastases cells were found to stain positively for the AT2R and the MasR. 


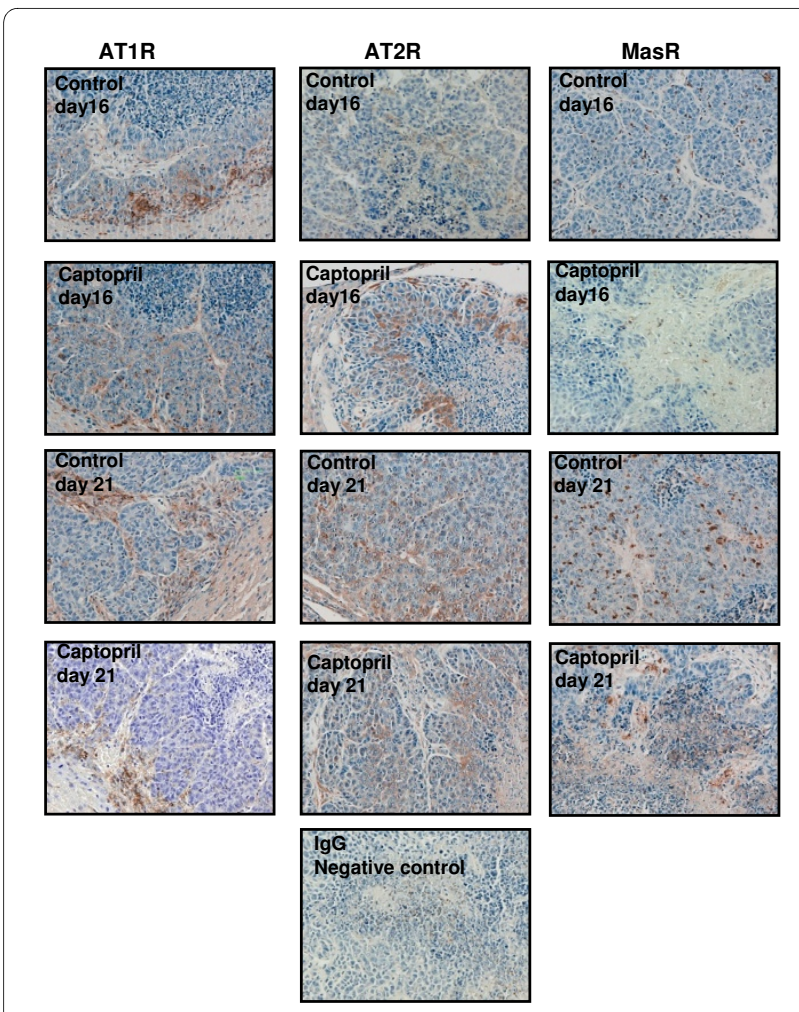

Figure 5 Immunohistochemical staining for the AT1R (A), AT2R $(B)$, and MasR (C) in control and captopril treated animals at day 16 and day 21. AT1R localised to cells within the stromal intrusions of CRC metastases with light staining also observed in tumor cells at the periphery (A). There appeared to be a greater number of AT1R-positive cells in and around CRC metastases in control compared to the captopril treated animals, supporting mRNA analysis for this receptor (Figure 2). AT2R protein localized to tumor cells only with no staining evident in the liver (B). MasR staining was found within and around the necrotic centre of CRC metastases and a greater number of MasR staining was observed in control groups as compared to the captopril treated groups (similar to the mRNA data presented in Figure 2). As with the AT2R, MasR staining was only evident in tumor cells.

These results support the finding that the mRNAs for both these alternative receptors was notably higher in CRC metastases than corresponding liver. The AT2R localized to cells near the proliferating rim (tumor-liver boundary), but, in contrast to the AT1R, did not extend to this edge. The MasR localized to cell in and around necrotic regions. The number of MasR-positive cells in control CRC metastases at day 16 and day 21 was noticeably higher and more consistent than captopril treated CRC metastases. Again these results support our mRNA analysis of this receptor.

\section{Discussion}

RAS expression has been described in various cancer cells and tissues and there is strong evidence that $\mathrm{ACE}$ inhibition can inhibit tumor growth [7,9,11,32-37]. In our previous study, we found that the administration of the ACE inhibitor captopril caused a marked reduction in the volume of CRC liver metastases and this was confirmed in the present study which also demonstrated a local RAS in CRC liver metastases that is distinct from the hepatic RAS [8].

\section{The RAS of colorectal cancer liver metastases is distinct from the liver RAS}

ACE, AT1R, MasR, and angiotensinogen were differentially expressed in control CRC liver metastases compared to the naïve (non-tumor bearing) and the tumorbearing liver. In particular, CRC metastases were characterised by high ACE and MasR expression, but low AT1R and angiotensinogen mRNA levels compared to the liver. These results indicate a distinct CRC cell-associated RAS.

These cancer cells are derived from transformed epithelial cells of the colon and the difference in RAS expression of these cells compared to the tumor-bearing and naïve liver most likely represents a combination of differences due to transformation and tissue origin (colon versus liver). Hepatocytes are the major source of circulating angiotensinogen and so it is perhaps not surprising that CRC metastases have lower angiotensinogen levels [38]. These results also imply that much of the ANG II available to drive growth of CRC liver metastases is derived from local host production of angiotensinogen, which is then converted to ANG II via high ACE expression in tumors. The high levels of tumor-derived ACE described here support reports of an up-regulation of ACE mRNA in primary CRCs compared to corresponding nonlesional tissues [39]. However, our immunohistochemical analysis suggests that at least some of the expression of ACE in CRC metastases is derived from infiltrating cells. It is known that infiltrating macrophages, which typically associate with stromal intrusions, express ACE [40].

MasR expression was also markedly higher in CRC metastases compared to the surrounding liver. The MasR, as well as binding ANG-(1-7), was originally described as a protoncogene based on its ability to transform NIH 3T3 cells and its up-regulation in tumors may represent a normal oncogenic pathway for CRC development [41]. However, transgenic mice overexpressing ANG-(1-7) do not have increased tumor formation and MasR overexpression in the retina leads to increased cell death without tumorgenicity suggesting that the MasR itself is not oncogenic [42]. Importantly, increased MasR expression may provide a target for initiating anti-tumor responses since MasR activation by ANG-(1-7) mediates a number of potentially anti-angiogenic and anti-proliferative effects. Indeed, ANG-(1-7) has been found to reduce serum-stimulated growth in human lung cancer cell lines [28].

AT1R protein is commonly expressed in several cancers such as the bladder, pancreatic, ovarian and renal cancer pulmonary metastasis [7-19]. However, in our study we 
found that AT1R expression was lower in CRC metastases compared to the surrounding liver. AT1R protein localized mainly to the stromal intrusions in liver metastases with only light staining in the cancer cells themselves and confined to those cells at the proliferating border of tumors. Given their location within the tumor desmoplasia and liver sinusoids many of these AT1R-positive cells are likely to be Kupffer cells, resident liver macrophages. Macrophages may contribute to tumor growth by producing growth factors that enhance angiogenesis. These infiltrating AT1R-positive cells may have a role in mediating the effects of RAS blockade on tumor growth.

The results presented here support the hypothesis that malignancies maintain a local RAS that reflects the tissue in which the primary tumor developed. However, our results do not preclude interactions between tumor and host RASs and it is likely that both have paracrine effects on the other.

\section{Captopril treatment alters expression of the RAS in tumors}

The significant reduction in ACE expression at day 16 following captopril treatment suggests that in addition to the inhibition of ACE activity, captopril also reduces ACE levels, presumably leading to an even greater inhibition of ANG II production. The timing of this reduction in ACE expression is of interest as it occurs during the critical exponential growth phase (day 10 to 19). However, in the late plateau stages (day 21 onwards) of CRC metastases growth, captopril treatment was associated with a reversion of ACE expression back to the levels seen in untreated tumors at day 21. In our previous study we stopped captopril treatment at day 21 and found survival was not significantly improved in treated animals compared to controls [8]. Our current results suggest a possible explanation for this, as the increased expression of ACE mRNA (and protein) at this time would require additional, or at least continued, captopril treatment to ensure sustained inhibition of ACE activity.

\section{Captopril altered the liver RAS}

It is likely that much of the ANG II postulated to drive growth of CRC metastases in the liver is derived from angiotensinogen expressed by the liver parenchyma. We also show that under captopril treatment angiotensinogen expression in the host liver was significantly reduced. Thus, in the captopril treated liver, the production of ANG II would be severely compromised by the inhibition of its conversion from ANG I, the preferential production of ANG-(1-7), and the reduction of angiotensinogen expression, all of which would contribute to the reduced availability of ANG II to support tumor growth $[43,44]$.

\section{Conclusions}

In conclusion, the present study provides evidence of a complete local RAS in both the normal and tumor-bear- ing mouse liver. We show a marked up-regulation of ACE during CRC metastases development, which would presumably favor CRC metastases growth by increasing production of ANG II. Captopril treatment reduced CRC metastases ACE expression during the period of rapid growth, but ACE expression increased at late stages (day 21). This increase in ACE expression would need to be taken into consideration if targeting ACE in anti-cancer therapies. High MasR expression in CRC metastases, but not in the liver, suggests that infusion of ANG-(1-7) may also inhibit growth of CRC metastases. The data presented here indicates that the tumor RAS may be differentially regulated from the adjacent liver RAS. This independence may allow treatments to negatively target the tumor RAS, while allowing the liver to function and respond as normal.

\section{Competing interests}

The authors declare that they have no competing interests.

\section{Authors' contributions}

JN carried out qRT-PCR and immunohistochemistry and drafted the manuscript. EA carried out ACE positive cell counts, established IHC protocols, and revised the manuscript. PA participated in the design of the study and manuscript revision. JZ established ACE IHC protocols. $\mathrm{CH}$ participated in the design of probes and primers for qRT-PCR. CC conceived of the study and revised the final manuscript. All authors have read and approved the final manuscript.

\section{Acknowledgements}

This work was supported by the Cancer Council of Victoria, Australian Rotary Health Research Fund and the Austin Health and Medical Research Fund.

\section{Author Details}

1Department of Surgery, The University of Melbourne, Austin Health, Heidelberg, Victoria, Australia and 2Department of Medicine, The University of Melbourne, Austin Health, Heidelberg, Victoria, Australia

Received: 12 November 2009 Accepted: 10 April 2010

Published: 10 April 2010

\section{References}

1. Global cancer rates could increase by $50 \%$ to 15 million by 2020 . World Cancer Report provides clear evidence that action on smoking, diet and infections can prevent one third of cancers, another third can be cured [http://www.who.int/mediacentre/news/releases/2003/pr27/en/]

2. Australian Institute of Health and Welfare (AlHW), Australasian Association of Cancer Registries (AACR): Cancer in Australia. In Cancer in Australia 2001. Cancer series number 28 Canberra: Australian Institute of Health and Welfare; 2004:6-25.

3. Huh JW, Park YA, Lee KY, Kim SA, Sohn SK: Recurrences after local excision for early rectal adenocarcinoma. Yonsei Med J 2009, 50:704-708.

4. Faerden AE, Naimy N, Wiik P, Reiertsen O, Weyessa S, Tronnes S, Andersen SN, Bakka A: Total mesorectal excision for rectal cancer: difference in outcome for low and high rectal cancer. Dis Colon Rectum 2005, 48:2224-2231.

5. Lever AF, Hole DJ, Gillis CR, McCallum IR, McInnes GT, MacKinnon PL, Meredith PA, Muurray LS, Reid JL, Robertson JWK: Do inhibitors of angiotensin-I-converting enzyme protect against risk of cancer? The Lancet 1998, 352:179-184.

6. Noguchi R, Yoshiji H, Kuriyama S, Yoshii J, Ikenaka Y, Yanase K, Namisaki T, Kitade M, Yamazaki M, Mitoro A, Tsujinoue H, Imazu H, Masaki T, Fukui H: Combination of interferon-beta and the angiotensin-converting enzyme inhibitor, perindopril, attenuates murine hepatocellular carcinoma development and angiogenesis. Clin Cancer Res 2003, 9:6038-6045.

7. Yasumatsu R, Nakashima T, Masuda M, Ito A, Kuratomi Y, Nakagawa T, Komune S: Effects of the angiotensin-I converting enzyme inhibitor 
perindopril on tumor growth and angiogenesis in head and neck squamous cell carcinoma cells. J Cancer Res Clin Oncol 2004, 130:567-573.

8. Neo JH, Malcontenti-Wilson C, Muralidharan V, Christophi C: Effect of ACE inhibitors and angiotensin II receptor antagonists in a mouse model of colorectal cancer liver metastases. J Gastroenterol Hepatol 2007, 22:577-584.

9. Volpert OV, Ward WF, Lingen MW, Chesler L, Solt DB, Johnson MD, Molteni A, Polverini PJ, Bouck NP: Captopril inhibits angiogenesis and slows the growth of experimental tumors in rats. J Clin Invest 1996, 98:671-679.

10. Attoub S, Gaben AM, Al-Salam S, Al Sultan MA, John A, Nicholls MG, Mester J, Petroianu G: Captopril as a potential inhibitor of lung tumor growth and metastasis. Ann N Y Acad Sci 2008, 1138:65-72.

11. Lang L: ACE Inhibitors May Reduce Esophageal Cancer Incidence. Gastroenterology 2006, 131:343-344.

12. Ronquist $G$, Rodríguez LA, Ruigómez A, Johansson S, Wallander MA, Frithz G, Svärdsudd K: Association between captopril, other antihypertensive drugs and risk of prostate cancer. Prostate 2004, 58:50-56

13. Herath CB, Warner FJ, Lubel JS, Dean RG, Jia Z, Lew RA, Smith Al, Burrell LM, Angus PW: Upregulation of hepatic angiotensin-converting enzyme 2 (ACE2) and angiotensin-(1-7) levels in experimental biliary fibrosis. $J$ Hepatol 2007, 47:387-395.

14. Paizis G, Cooper ME, Schembri JM, Tikellis C, Burrell LM, Angus PW: Upregulation of components of the renin-angiotensin system in the bile duct-ligated rat liver. Gastroenterology 2002, 123:1667-1676.

15. Muramatsu M, Katada J, Hayashi I, Majima M: Chymase as a proangiogenic factor. A possible involvement of chymaseangiotensin-dependent pathway in the hamster sponge angiogenesis model. J Biol Chem 2000, 275:5545-5552.

16. Tucker CE, Chen LS, Judkins MB, Farmer JA, Gill SC, Drolet DW: Detection and plasma pharmacokinetics of an anti-vascular endothelial growth factor oligonucleotide-aptamer (NX1838) in rhesus monkeys. $f$ Chromatogr B Biomed Sci Appl 1999, 732:23-12.

17. Uemura H, Ishiguro H, Nakaigawa N, Nagashima Y, Miyoshi Y, Fujinami $K$, Sakaguchi A, Kubota Y: Angiotensin II receptor blocker shows antiproliferative activity in prostate cancer cells: a possibility of tyrosine kinase inhibitor of growth factor. Mol Cancer Ther 2003 2:1139-1147.

18. Miyajima A, Kosaka T, Asano T, Seta K, Kawai T, Hayakawa M: Angiotensin Il type I antagonist prevents pulmonary metastasis of murine renal cancer by inhibiting tumor angiogenesis. Cancer Res 2002, 62:4176-4179.

19. Ohta T, Amaya K, Yi S, Kitagawa H, Kayahara M, Ninomiya I, Fushida S, Fujimura T, Nishimura G, Shimizu K, Miwa K: Angiotensin converting enzyme-independent, local angiotensin II-generation in human pancreatic ductal cancer tissues. Int J Oncol 2003, 23:593-598.

20. Stoll M, Steckelings UM, Paul M, Bottari SP, Metzger R, Unger T: The angiotensin AT2-receptor mediates inhibition of cell proliferation in coronary endothelial cells. J Clin Invest 1995, 95:651-657.

21. Nakajima M, Hutchinson HG, Fujinaga M, Hayashida W, Morishita R, Zhang L, Horiuchi M, Pratt RE, Dzau VJ: The angiotensin II type 2 (AT2) receptor antagonizes the growth effects of the AT1 receptor: gain-of-function study using gene transfer. Proc Natl Acad Sci USA 1995, 92:10663-10667.

22. Tipnis SR, Hooper NM, Hyde R, Karran E, Christie G, Turner AJ: A human homolog of angiotensin-converting enzyme. Cloning and functional expression as a captopril-insensitive carboxypeptidase. J Biol Chem 2000, 275:33238-33243

23. Donoghue M, Hsieh F, Baronas E, Godbout K, Gosselin M, Stagliano N Donovan M, Woolf B, Robison K, Jeyaseelan R, Breitbart RE, Acton S: A novel angiotensin-converting enzyme-related carboxypeptidase (ACE2) converts angiotensin I to angiotensin 1-9. Circ Res 2000, 87:E1-9.

24. Burrell LM, Johnston Cl, Tikellis C, Cooper ME: CE2, a new regulator of the renin-angiotensin system. Trends Endocrinol Metab 2004, 15:166-169.

25. Machado RD, Santos RA, Andrade SP: Opposing actions of angiotensins on angiogenesis. Life Sci 2000, 66:67-76.

26. Machado RD, Santos RA, Andrade SP: Mechanisms of angiotensin-(1-7)induced inhibition of angiogenesis. Am J Physiol Regul Integr Comp Physiol 2001, 280:R994-R1000.

27. Freeman EJ, Chisolm GM, Ferrario CM, Tallant EA: Angiotensin-(1-7) inhibits vascular smooth muscle cell growth. Hypertension 1996, 28:104-108.
28. Gallagher PE, Tallant EA: Inhibition of human lung cancer cell growth by angiotensin-(1-7). Carcinogenesis 2004, 25:2045-2052.

29. Rodgers K, Xiong S, Felix J, Roda N, Espinoza T, Maldonado S, Dizerega G: Development of angiotensin (1-7) as an agent to accelerate dermal repair. Wound Repair Regen 2001, 9:238-247.

30. Ellefson DD, diZerega GS, Espinoza T, Roda N, Maldonado S, Rodgers KE: Synergistic effects of co-administration of angiotensin 1-7 and Neupogen on hematopoietic recovery in mice. Cancer Chemother Pharmacol 2004, 53:15-24.

31. Kuruppu D, Christophi C, O'Brien PE: Microvascular architecture of hepatic metastases in a mouse model. HPB Surg 1997, 10:149-157. discussion 158

32. Unger T, Gohlke P: Tissue renin-angiotensin systems in the heart and vasculature: possible involvement in the cardiovascular actions of converting enzyme inhibitors. Am J Cardiol 1990, 65:31-101.

33. Tahmasebi M, Barker S, Puddefoot JR, Vinson GP: Localisation of reninangiotensin system (RAS) components in breast. Br J Cancer 2006, 95:67-74.

34. Ganong WF: The brain renin-angiotensin system. Annu Rev Physiol 1984, 46:17-31.

35. Fujimoto Y, Sasaki T, Tsuchida A, Chayama K: Angiotensin II type 1 receptor expression in human pancreatic cancer and growth inhibition by angiotensin II type 1 receptor antagonist. FEBS Lett 2001, 495:197-200.

36. Hii SI, Nicol DL, Gotley DC, Thompson LC, Green MK, Jonsson JR: Captopril inhibits tumor growth in a xenograft model of human renal cell carcinoma. British Journal of Cancer 1998, 77:880-883.

37. Ronquist $G$, Rodriguez $L A$, Ruigomez A, Johansson S, Wallander MA, Frithz G, Svardsudd K: Association between captopril, other antihypertensive drugs and risk of prostate cancer. Prostate 2004, 58:50-56.

38. Celerier J, Cruz A, Lamande N, Gasc JM, Corvol P: Angiotensinogen and its cleaved derivatives inhibit angiogenesis. Hypertension 2002, 39:224-228.

39. Rocken C, Neumann K, Carl-McGrath S, Lage H, Ebert MP, Dierkes J, Jacobi CA, Kalmuk S, Neuhaus P, Neumann U: The gene polymorphism of the angiotensin I-converting enzyme correlates with tumor size and patient survival in colorectal cancer patients. Neoplasia 2007, 9:716-722.

40. Leung PS, Suen PM, Ip SP, Yip CK, Chen G, Lai PB: Expression and localization of AT1 receptors in hepatic Kupffer cells: its potential role in regulating a fibrogenic response. Regul Pept 2003, 116:61-69.

41. Young D, Waitches G, Birchmeier C, Fasano O, Wigler M: Isolation and characterization of a new cellular oncogene encoding a protein with multiple potential transmembrane domains. Cell 1986, 45:711-719.

42. Alenina N, Xu P, Rentzsch B, Patkin EL, Bader M: Genetically altered animal models for Mas and angiotensin-(1-7). Exp Physiol 2008, 93:528-537.

43. Ferrario CM, Jessup J, Gallagher PE, Averill DB, Brosnihan KB, Ann Tallant E, Smith RD, Chappell MC: Effects of renin-angiotensin system blockade on renal angiotensin-(1-7) forming enzymes and receptors. Kidney Int 2005, 68:2189-2196

44. Azizi M, Menard J: Combined blockade of the renin-angiotensin system with angiotensin-converting enzyme inhibitors and angiotensin II type 1 receptor antagonists. Circulation 2004, 109:2492-2499.

\section{Pre-publication history}

The pre-publication history for this paper can be accessed here: http://www.biomedcentral.com/1471-2407/10/134/prepub

doi: 10.1186/1471-2407-10-134

Cite this article as: Neo et al., Changes in the renin angiotensin system during the development of colorectal cancer liver metastases BMC Cancer 2010, 10:134 